\title{
Performance of pearl millet genotypes under irrigated and rainfed conditions at Hisar, India
}

\author{
Arvind Kumar Yadav ${ }^{* 1}$, Anil Kumar ${ }^{1}$, Jagdev Singh ${ }^{1}$, R.D. Jat ${ }^{1}$, H.S. Jat ${ }^{2}$, Ashim Datta ${ }^{3}$, \\ Kuldeep Singh ${ }^{4}$ and Rakesh Chaudhary ${ }^{1}$ \\ ${ }^{1}$ Department of Agronomy, Chaudhary Charan Singh Haryana Agricultural University- Hisar (Haryana)-125001, \\ INDIA \\ ${ }^{2}$ Research Platform Coordinator, CIMMYT-Karnal, India, New Delhi-110012, INDIA \\ ${ }^{3}$ Division of Soil and Crop Management, Central Soil Salinity Research Institute-Karnal (Haryana)-132001, INDIA \\ ${ }^{4}$ Department of Soil Science, Chaudhary Charan Singh Haryana Agricultural University- Hisar (Haryana)-125001, \\ INDIA \\ *Corresponding author.E-mail: yadav.arvind580@gmail.com
}

Received: August 18, 2014; Revised received: September 04, 2014 .Accepted: September 23, 2014

\begin{abstract}
A field experiment was carried out at Research Farm of Chaudhary Charan Singh Haryana Agricultural University, Hisar, India to evaluate the performance of pearl millet genotypes (HHB 67 'Improved', HHB 197, HHB 223 and HHB 234) under different environment (rainfed and irrigated). Results showed that irrigated condition recorded significantly $(p<0.05)$ higher plant height, dry matter accumulation, root dry weight, ear head girth, test weight and yield of pearl millet than rainfed condition. Root length was significantly $(p<0.05)$ higher under rainfed than irrigated condition. Genotypes were found significant $(p<0.05)$ with respect to plant height at harvest and HHB 234 recorded higher plant height. Genotype HHB 223 recorded higher earhead girth $(2.6 \mathrm{~cm})$ and test weight $(11.16$ g) compared to other genotypes. Interaction effect was also found significant $(p<0.05)$ with respect to plant height, dry matter accumulation, root length and weight and yield. These were higher in genotype HHB 223 and HHB 234 under irrigated and rainfed condition respectively but at 20 days after sowing, longest root was observed in genotype HHB 67 'Improved' under rainfed condition and genotype HHB 197 under irrigated condition. To examine the performance of pearl millet genotypes in terms of survivality and yield potential, evaluation trials are necessary under different environment. Therefore, release of those varieties under different situations are essential for the sustainability of the fragile arid and semi arid regions of country.
\end{abstract}

Keywords: Genotypes, Irrigated, Pearl millet, Rainfed

\section{INTRODUCTION}

Pearl millet is the sixth most important cereal in the world after wheat (Triticum aestivum), rice (Oryza sativa), maize (Zea mays L.), barley (Hordeum vulgare) and sorghum (Sorghum bicolor) (Singh et al., 2003). It is a major crop in the semi-arid dry land regions in Southeast Asia and Africa (Henry and Kettlewell 1996; Baltensperger 2002). The most recent estimates put global rainfed croplands at 1.75 billion hectares at the end of the last millennium, which are about 5.5 times the irrigated areas of the world. In India, rainfed area accounts for nearly two-thirds of total cropped area and generates nearly half of the total value of agricultural output. In these regions, around 300 million people of whom $30-40 \%$ are poor depend on rainfed cultivation for their sustenance. Improving crop yield under rainfed condition is important, both to maintain food security and to improve the livelihoods of the poor. Also, with a depleting resource base and with stagnating productivity in irrigated areas, improving the productivity of irrigated agriculture is necessary to maintain food security at the national scale (Rosegrant et al. 2002). The genotype used in this study was newly released from Chaudhary Charan Singh Haryana Agricultural University so the evaluation of these genotypes under different condition is necessary for sustainable crop production. To keep above view in mind this study was conducted to evaluate comparative performance of pearl millet genotypes under rainfed and irrigated conditions.

\section{MATERIALS AND METHODS}

A field experiment was conducted during kharif season of 2011 and 2012 in micro plot at Research Area of Chaudhary Charan Singh Haryana Agricultural University, Hisar, India $\left(29^{\circ} 17^{\prime} \mathrm{N}\right.$ latitude and $75^{\circ} 47^{\prime}$ E longitude at an altitude of 215.2 meters above mean sea level). The research site is located in the subtropical climatic zone of India with minimum and maximum temperature of 0 and $48^{\circ} \mathrm{C}$, respectively. 
The average annual precipitation was estimated to 400 $\mathrm{mm}$, and most of which was received from South-West monsoon during July to September. The rainfall was highly erratic with coefficient of variation ranging between 30-50 per cent during the crop seasons. The weather parameters of two growing seasons are shown in Fig 1. The soil had a sandy texture, $\mathrm{pH}(1: 2 \mathrm{soil} /$ water ratio) of 8.5 and electrical conductivity (1:2 soil/ water ratio) of $0.15 \mathrm{dS} \mathrm{m} \mathrm{m}^{-1}, 0.15$ percent organic carbon, $65.2 \mathrm{~kg} \mathrm{ha}^{-1}$ available nitrogen, $7.37 \mathrm{~kg} \mathrm{ha}^{-1}$ available phosphorus and $160 \mathrm{~kg} \mathrm{ha}^{-1}$ available potassium. At each cropping season, the trials were conducted under rainfed and irrigated (three irrigations applied to cope drought stress) conditions with four pearl millet genotypes i.e., HHB 67 (Improved), HHB 197, HHB 223 and HHB 234. Pre sowing irrigation was applied for uniform germination because no rainfall was received at the time of sowing. The experiment was laid out in a factorial randomized block design with three replications. The seed rate was $5 \mathrm{~kg} \mathrm{ha}^{-1}$ with a spacing of $45 \mathrm{~cm} \times 10 \mathrm{~cm}$. The plots were fertilized as full dose of phosphorus $(62.5 \mathrm{~kg}$ under irrigated and $20 \mathrm{~kg} \mathrm{ha}^{-1}$ for rainfed condition) and half dose of nitrogen $(62.5 \mathrm{~kg}$ for irrigated and $20 \mathrm{~kg}$ $\mathrm{ha}^{-1}$ under rainfed condition) were applied as per the treatments at the time of sowing and rest of the nitrogen was top dressed after thinning and gap filling. All agronomic practices were carried out uniformly for all treatments.

The plant height in centimetres was recorded by measuring the height from ground level to the base of youngest fully opened leaf before panicle emergence. After panicle emergence, height was recorded from the base of the plant to the tip of the panicle. Five randomly selected plants from each plot were used to record the dry matter production at various growth stages and then dried in oven at $60 \pm 5^{\circ} \mathrm{C}$ until constant weight was attained. Soil adhered to plant roots was washed by the water from the micro plot and than roots were collected and length was measured by scale in centimetre. Then roots were dried in an oven at $60 \pm$ $5^{0} \mathrm{C}$ until constant weight was attained. The ear head girth was measured by vernier caliper at maximum thickness of earhead. 1000 grains from each sample were counted by seed counter and their weight was recorded. Net area from each plot was harvested and threshed separately. The grain yield from net plot (3.15 x $1 \mathrm{~m})$ was recorded and computed as grain yield in $\mathrm{q} \mathrm{ha}^{-1}$.

\section{RESULTS AND DISCUSSION}

Plant height: The crop recorded significantly $(\mathrm{p}<0.05)$ taller plants at all the stages of crop growth under irrigated environment than rainfed condition (Table 1). Our results are also in agreement with Saifullah et al. 2011 who reported that plant height was increased significantly $(\mathrm{p}<0.05)$ with increase in irrigation frequency. Genotypes were also found significant $(\mathrm{p}<0.05)$ at harvest stage and the maximum plant height was recorded by HHB 234 this was due to differential maturity duration of genotypes (Kumar, 2001 and Parihar, 2005).

Regarding the interaction effect between environment and genotypes on plant height the data presented in Table 1 indicates that the genotype HHB 223 attained maximum plant height under irrigated condition while under rainfed, it had the lowest height. Under rainfed condition, genotype HHB 234 recorded higher plant height than other genotypes. Similar results of difference in plant height among different tested pearl millet varieties viz; Tandojam Millet Selection, NARC-I, Tift-383, ExD 2 Bulk, Quetta Millet Selection, DBR-3, NARC-5, Pothwar Selection and Check MB-87 have been reported at Faisalabad by Naeem et al. (2002) and Naeem et al. (2003).

Dry matter accumulation : Irrigated condition recorded significantly $(\mathrm{p}<0.05)$ higher dry matter accumulation than rainfed condition. Interaction effect showed that under irrigated condition, genotype HHB 223 recorded higher dry matter accumulation but under rainfed condition reverse trend was observed (Fig 2). This may be due to its susceptibility to water deficit. The genotypes HHB 234 and HHB 67 'Improved' recorded higher dry matter accumulation in comparison to other genotypes under rainfed condition. Better dry-matter accumulation in these genotypes may be due to more active photosynthetic area (leaf area) that causes more expansion of root and shoot (Table 2 and Fig 2). This indicated that these genotypes thrive well under moisture stress condition. Such effect may be due to the genetic variability between the genotypes. HHB 234 and HHB 67 'Improved' had favourable gene action against stress condition. The significance of genetic variability among pearl millet genotypes was also reported by Damame et al., (2013) at Rahuri and by Yadav (2014) at Hisar.

Rooting characteristics: The crop had longer root (Table 2) under rainfed than irrigated condition. Root length under rainfed condition was 1.6, 8.6, 8.8 and 7.1 $\mathrm{cm}$ more at 20, 40, 60 days after sowing and harvest, respectively compared to irrigated condition. Roots have the tendency for elongation in search of water and nutrients under the limited conditions, therefore, having more elongation under the rainfed condition. The increase in the rate of root growth in response to drought depends mostly on the type of plant used, how it is affected by drought and their adaptability to severe conditions either by growing to deeper levels and branching extensively in the soil so as to draw all their water needs (Tyagi et al., 1999; Sanchez et al., 2006). Longer root were noticed under rainfed condition by the genotype HHB 234 at all the stages except at 20 days after sowing where it was longest in HHB 67 'Improved' (Tables 2). Under irrigated environment, HHB 223 had longer roots in comparison to all other genotypes at all the stage (Tables 2) except at 20 days 
after sowing where it was longest in the genotype HHB 197.

Higher root biomass was recorded under irrigated condition in all the tested genotypes. The genotype HHB 223 produced higher root biomass at all the stages (Fig 2) under irrigated condition but under rainfed condition this genotype recorded lower root biomass. Under rainfed condition genotype HHB 234 gain higher root biomass compare to other genotypes. Nour and Weibal (1978) also observed that the resistant varieties of sorghum had greater root weight and volume as well as longer roots than less drought resistant ones.

Yield attributing character: Pearl millet genotypes recorded significantly $(\mathrm{p}<0.05)$ more earhead girth and test weight under irrigated compared to rainfed condition (Table 3). The superiority of such trait may be due to the exists of soil moisture content which led to favorable nutritional environment in root zone which led to higher uptake of soluble nutrients and this might have increased the rate of photosynthesis translocation from stems and leaves to the sink. The present results are in agreement with those obtained by Maiti and Bidinger (1981) in pearl millet at Hyderabad; Tabosa et al. (1999) in millet and sorghum varieties at Brazil; Zerbini and Thomas (2003) in millet and sorghum varieties at South Asia and Yadav and Kumar (2013) in pearl millet at Hisar.

Pearl millet genotype HHB 223 recorded maximum earhead girth and test weight whereas, minimum was in the HHB 67 'Improved'. Such effect was due to the genetic variability between the pearl millet genotypes (Khippal and Hooda 2002). Kumar et al. (2014) also found significant differences among the 26 hybrids of pearl millett for earhead girth and test weight at Bawal, Haryana.The interaction between environment and genotypes with respect to earhead girth and test weight was not found significant.

Grain yield (q ha $\left.\mathbf{~ h}^{-1}\right)$ : Under irrigated condition higher grain yield (31.19 $\mathrm{q} \mathrm{ha}^{-1}$ ) was observed than rainfed condition (24.29 q ha-1) (Table 4). The better performance of pearl millet in terms of yield under irrigated condition might be due to increased soil-moisture content which improved internal water status and growth of plant. Thus, higher rate of water flow from the soil to plant helps in better stomatal conductance and more leaf area which help to sustain better transpiration in pearl millet thereby improving the ear head numbers, its size (in terms of length and girth), 1000 grain weight and final grain yield. Beneficial effects of irrigation on yield attributes, grain and stover yields of pearl millet were also reported by Khippal and Hooda (2002); Imma and Jose (2006); Saifullah et al. (2011).

The genotypes behaved differently under two environments. Interaction effect showed that maximum grain yield of $34.11 \mathrm{q} \mathrm{ha}^{-1}$ was recorded by the genotype HHB 223 and it was statistically at par with genotype HHB 197 


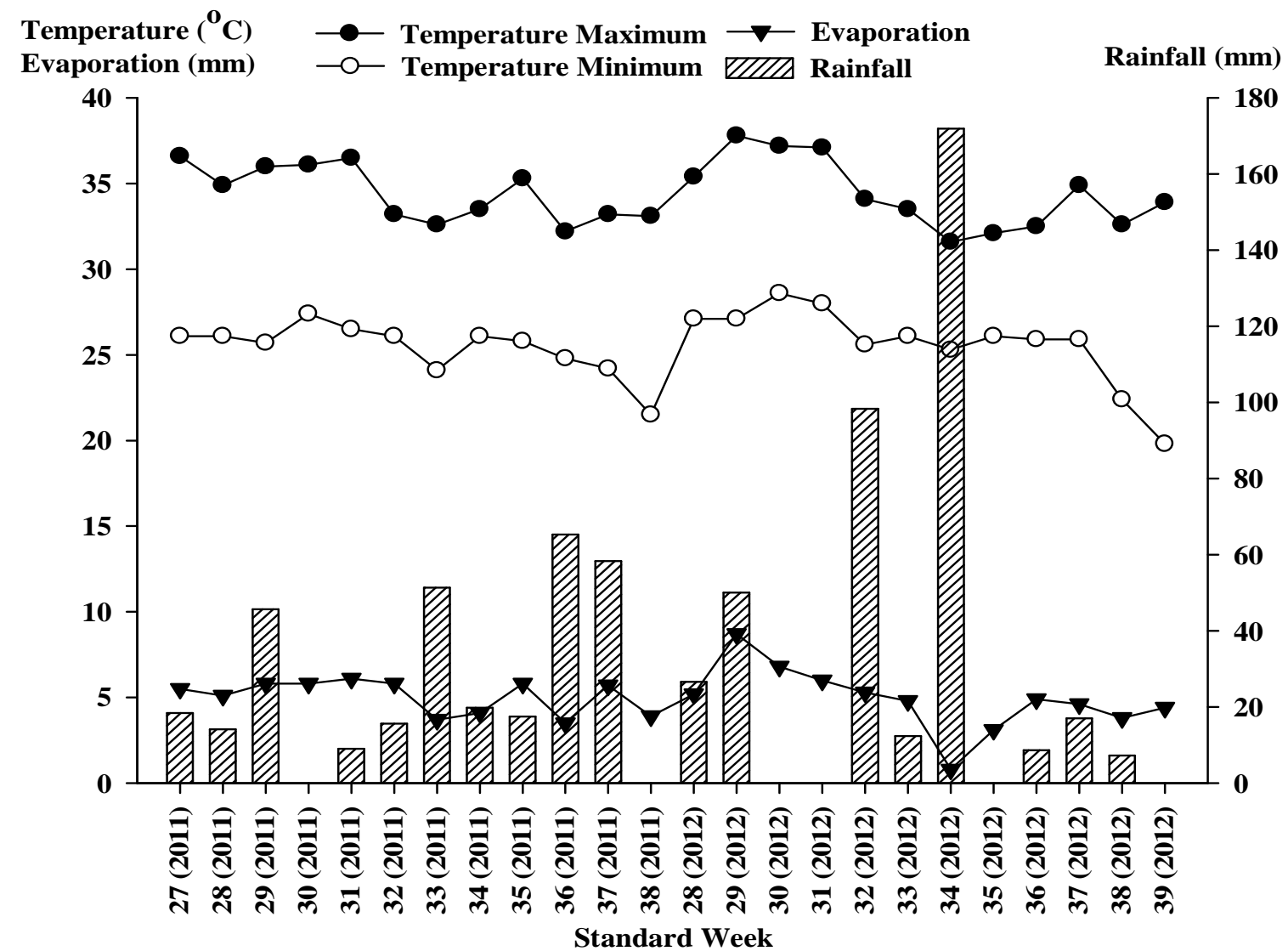

Fig. 1. Meteorological observations during crop seasons.

\section{Rainfed}

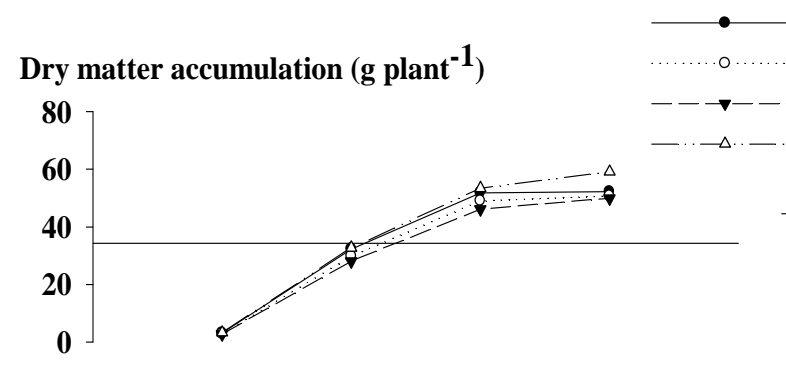

Root weight (g plant ${ }^{-1}$ )

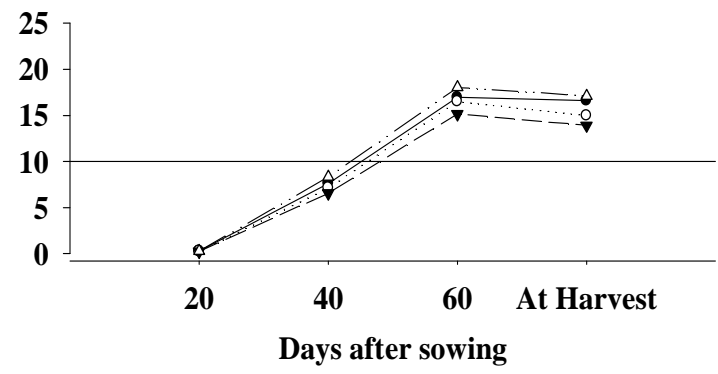

Irrigated

HHB 67 Imp.

HHB 197 Dry matter accumulation (g plant ${ }^{-1}$ )

HHB 223

HHB 234
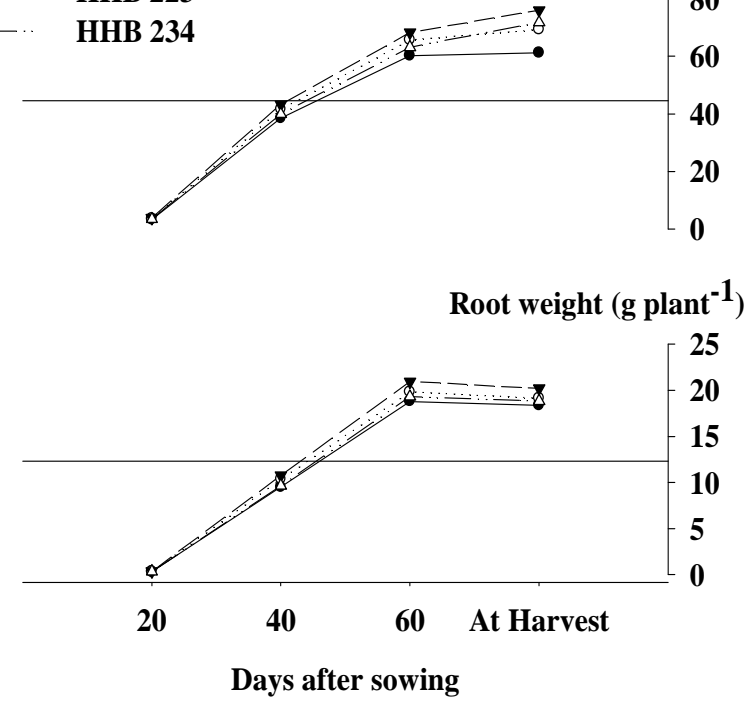

Fig. 2. Dry matter accumulation and root dry weight under rainfed and irrigated condition. (Imp.-Improved)

(31.81 q ha $\mathrm{h}^{-1}$ ) under irrigated condition (Table 4).

However, under rainfed situation, this genotype was the lowest yielder. The genotypes HHB 234 and HHB 67 'Improved' had significantly $(\mathrm{p}<0.05)$ higher grain yield under rainfed condition as these genotypes thrive well under moisture stress condition. Similarly significant differences in pearl millet genotypes with respect to grain yield under different condition were also reported by Patil (2005); Maqsood and Ali (2007). 


\section{Conclusions}

Our results showed that the genotypes HHB 223 and HHB 197 gave better performance in terms of growth and yield under irrigated condition whereas under rainfed these genotypes showed poor performance. Under rainfed condition, genotypes HHB 234 and HHB 67 'Improved' found better in growth and yield than other genotypes.

\section{ACKNOWLEDGMENTS}

The authors are grateful to Chaudhary Charan Singh Haryana Agricultural University, for providing necessary facility during research.

\section{REFERENCES}

Baltensperger, D.D. (2002). Progress with proso, pearl and other millets pp. 100-103, in Janick J and Whipkey A (ed.) Trends in New Crops and New Uses. Proc. New Crops and New Uses Strength in Diversity, 5th. Atlanta, GA. ASHS Press, Alexandria VA.

Henry, R.J. and Kettlewell, P.S. (1996). Cereal grain quality. London: Chapman \& Hall.

Damame, S.V., Bhingarde, R.N. and Pathan, S.H. (2013). Effect of different nitrogen levels on nutritional quality and nitrate nirogen accumulation in forage pearl millet genotypes grown under rainfed conditions. Forage Research, 39: 93-95.

Imma, F. and Jose, M. (2006). Comparative response of maize (Zea mays L.) and sorghum (Sorghum bicolor L. Moench) to deficit irrigation in a Mediterranean environment. Agricultural water management, 83: 135143.

Khippal, A. and Hooda, R.S. (2002). Effect of pearl millet hybrids/composites to irrigation applied at different stages of growth. Haryana Journal of Agronomy, 18: 75 -77 .

Kumar, M. (2001). Response of irrigated pearl millet hybrid to nitrogen. M.Sc. thesis. Department of Agronomy, Chaudhary Charan Singh Haryana Agricultural University, Hisar, India.

Kumar, Y., Lamba, R.A.S., Yadav, H.P., Kumar, R. and Dev vart. (2014). Studies on variability and character association under rainfed conditions in pearl millet (Pennisetum glaucum L.) hybrids. Forage Research, 39: 175-178.

Maiti, R.K. and Bidinger, F.R. (1981). Growth and development of pearl millet plant. ICRISAT Research Bulletin, pp 12

Maqsood, M. and Ali, S.N.A. (2007). Effects of environmental stress on growth, radiation use efficiency and yield of finger millet (Eleucine coracana). Pakistan Journal of Botany, 39: 463-474.

Naeem, M., Chohan, M.S.M., Khan, A.H. and Salahuddin, S. (2002). Evaluation of different varieties of pearl millet for green fodder yield potential. Asian Journal of Plant Science, 1: 326-327.

Naeem, M., Chohan, M.S.M., Khan, A.H. and Salahuddin, S. (2003). Study of green fodder yield potential and its components of different pearl millet verities under irrigated condition of Faisalabad. Asian Journal of Plant Science, 2: 74-76.

Nour, M.A. and Weibal, D.E. (1978). Evaluation of root characteristics in grain sorghum. Agronomy Journal, 70: 217-218.

Parihar, M.D. (2005). Effect of nitrogen application on phenology, growth, yield and quality of pearl millet hybrid under limited water supply. M.Sc. thesis. Department of Agronomy, Chaudhary Charan Singh Haryana Agricultural University, Hisar, India.

Patil, S.L. (2005). Dry matter production, yield, water uses efficiency and economics of winter sorghum varieties under drought conditions in vertisols of South India. Crop Research, 29: 185-91.

Rosegrant, M., Cai, X., Cline, S. and Nakagawa, N. (2002). The role of rainfed agriculture in the future of global food production. EPTD discussion paper 90, IFPRI: Washington DC .

Saifullah, J.A., Munsif, F. and Arif, M. (2011). Performance of millet varieties under different irrigation levels. Sarhad Journal of Agriculture, 27: 1-6.

Sanchez-Blanco, J., Fernandez, T., Morales, A., Morte, A. and Alarcon, J.J. (2006). Variation in water stress, gas exchange and growth in Rasmanrins officinalis plants infected with Glamus deserticola under drought conditions. Journal of Plant Physiology, 161: 675-82.

Singh, R., Singh, D.P. and Tyagi, P.K. (2003). Effect of Azotobacter, farmyard manure and nitrogen fertilization on productivity of pearl millet hybrids (Pennisetum glaucum) in semi-arid tropical environment. Archives of Agronomy and Soil Science, 49: 21-24.

Tabosa, J.N., Andrews, D.J., Tavares, J.J. and Azevedo-Neto, A.D. (1999). Comparison among forage millet and sorghum varieties in semi-arid pernambuco, Brazil: yield and quality. International Sorghum Millet Newsletter, 40: 3-6.

Tyagi, A., Kumar, N. and Sairam, R.K. (1999). Efficiency of RWC, membrane stability, osmotic potential, endogenous $\mathrm{ABA}$ and root biomass as indices for selection against water stress in rice. Indian Journal of Plant Physiology, 4: 302-306.

Yadav, A.K. (2014). Agrophysiological traits for drought tolerance in pearl miller. Ph.D. thesis. Department of Agronomy, Chaudhary Charan Singh Haryana Agricultural University, Hisar, India.

Yadav, A.K. and Kumar, A. (2013). Comparative performance of pearl millet genotypes in terms of yield and quality under different environment. Forage Research, 39: 31-35.

Zerbini, E. and Thomas, D. (2003). Opportunities for improvement of nutritive value in sorghum and pearl millet residues in south Asia through genetic enhancement. Field Crop Research, 84: 3-15. 